Ideals of Science and Faith. Easays by varions anthors, edited by the Rev. J. E. HAND. London : George Allen, 1804. Pp. xix, 8B8.

This volume consists of a number of essays brought together with the design presumably of illustrating the respective attitudes of brosd-minded scientific and religious thinkers towards each other's problems at the present time. The representatives of ecience are Sir Oliver Lodge (whose article in the Hibber Journal is here reprinted), Profs. J. A. Thomson, Geddes and Muirhead, Mr. Victor Branford and Mr. Bertrand Russell. The representatives of religion are the Reve. John Kelman, Ronald Bayne, Philip N. Waggett and Mr. Wilfrid Ward.

Of the book as a whole it is impossible to speak favourably. There has been little or no attempt to eecure consistency in the general method of treatrnent. Some of the writers seem hardly to know what is expected from them, others seem to trake the opportunity to discourse on their favourite thenes. There is thus a good deal in the book that has vary little bearing upon the main sabject, e.g., the essay in which Prof. Geddes expounds his views on educstion, and practically all the essays on the religious side except that of Mr. Wilfrid Ward. In the case of the religious essayista, however, it is perhaps a sufficient apology to mention the subjects on which they were apparently asked to write: the Presbyterim view, or the Church of tingland view, of the relations of religion and science. There is wore meaning, of course, in spesking of a specifically Catholic view of the relations of religion and acience, and Mr. Wilfrid Ward's short essay, one of the best in the book, is a very able statement and defence of the attitude of the Roman Church towards a progressive secular science. The various scientific essays are of varions merit. Prof. Muirhead's "Psychological Apprasch" (all the essays are "A pproaches") is a business-like statement of the limits of mechanical explanation. But the soientific expositions of Prof. Geddes and Mr. Branford suffer from defects which the following two quotations may respectively serve to indicste: "If the individual is the product of his ancestry, a transient whirlpool in the stream of life, a moseic of hereditary contributions from many forebears, a chip of the old block, a detachable pendant on the eternal-bead-8tring of germ-cells," etc. "The payohic products and processes of human evolution (Language and Literature, Science and the Fine Arts, Industrial aptitnde and Religious capacity) have, in their earlier phases at least, been developed mainly by art and transmitted mainly by ceremonial. Art and ceremonial may, from a certain standpoint, be regarded as sociological structures, corresponding to what paychologically is the function of educability; and educability itself is, as Prof. Ray Lankester has well shown, the psychological correlate of what biologically is a surplusege of cerebral development beyond the needs of a material struggle for life." Why Mr. Russell's paper, here reprinted under the title of "An Ethioal Approach," has been included in the volume one is at a loss to conjecture. His tones are in singular contrast with those that prevail in the rest of the book. "Brief and powerless is man's life; on him and all his race the slow sure doom falls pitiless and dark. Blind to good and evil, reckless of destruction, ounipotent matter rolls on its relentless way."

\title{
H. BABEBR
}

Scientific Fact and Motaphysical Realify. By Robrat Brandon Arnold. Macmillan \& Co., 1904 . Pp. xi, 860 .

The main object of this work is seid to be "the furtherance of efforts to bring the developments of science into touch with the point of view of 
metaphysics". (When will writers on philosophical sabjects cease abusing that well-intentioned but somewhat intractable metaphor ' the point. of view'? Their style would gain in clearness and elegance if they would employ it more sparingly and more correctly.)

The book is an ambitious attempt to construct a complete theory of the universe by one who is equally familiar with the most recent writings on Natural Science, Paychology and pure Philosophy. Unfortunately neither wide reading nor a taste for speculation dealing with ultiruate problems can ensure metaphysical acumen. The volnme before us can bardly be said to be distinguished either for the cogency of its argumentation or the value of its conclusions. 'Totalisation' is the technical term with which Mr. Arnold proposes to unlock all closed doors. 'Mind ' . . 'is the totalisation of its own material body.' But mind can be 'active,' as in the animals, without being 'actual,' $a$ s it is in man, in whom alone we find introspection: Bat mind as known in introspection is described only in metaphorical terms as the 'flash of consciousness' in which the neural processes are 'totalised'. A curiosity of the present work is a theory of 'material images' interposing between an object and the true 'mental' image; this reminds one strangely of the scholastic doctrine of sensible forms. A discussion on Human Immortality concludes a volume which is certainly quite up to date, for it contains a reference to the Prime Minister's recent address at Cambridge and the presence of the Russian volunteer cruisers in the Red Bea!

G. R. T. Ross.

Lo Neo-Criticioms de Charles Renouvior. Theorie de la Connaisance at do la Certitude. Par E. Jassegse. Iouvain et Paris, 1804. Pp. viii, B18.

Of all the lives devoted to philosophy that of Renouvier wes one of the longest, most laborious and most heroic. At all events, it would be hard to parallel the spectacle presented by the last years of a asge of eighty-five and more publishing every year a new important volume on the problems dear to his heart, and on bis very desthbed delivering to his disciple, M. Prat, his last message to mankind. It is no wonder therefore that 80 remarkable a personality and 80 voluminons a writer should have speedily fallen a victim to the commentating critio who preys upon the systems of the dead so soon as their authors are no longer alive to explain the difficulties that are suggested by their viewa Not that Dr. Janseens is an unfarourable specimen of his kind; only it seems a pity that Ronouvier did not fall to one capable of taking a larger and more sympathetic viow of his achievement. Dr. Janssens' study is written trom a Roman Catholic point of view, and hes not forgotten the radical republicanism and Protestant affiliations of Renouvier. Still its biographical sketch is interesting, and the exposition of his doctrine also will be found useful, even though it is avowedly incomplete. It is restricted to his theory of knowledge and certitude, and it may be donbted, whether in so 'personalist' a thinker this really reaches to the core of the system. It is not surpriang that Dr. Janssens should lay most emphasis on the festures he has stadied, and regard the Neo-criticism as the most essential sspect of Renouvier, but when one considers the cheracter of his sphere of influence, it will be found to lie ratber in the mighty impetus he has given to the Voluntariam and Personalism of the present day. For these ressons Dr. Janssens' criticism seems somewhat ineffective and lacking in penetration. To find, ag., as the outcome of a long discussion the conclusion that time is neither wholly subjective 